\title{
Estudo Hidromorfológico de Bacia Hidrográfica Urbana em Goiânia/GO
}

\author{
Hidromorphology study of urban river basin in Goiânia/GO \\ Vanessa Romero ${ }^{1}$, Klebber Teodomiro Martins Formiga ${ }^{1}$ e Francisco Fernando Noronha Marcuzzo ${ }^{2}$ \\ ${ }^{1}$ Universidade Federal de Goiás \\ vromero.fe@gmail.com; klebber.formiga@gmail.com \\ ${ }^{2}$ CPRM - Serviço Geológico do Brasil \\ fmarcuzzo@gmail.com
}

\section{Resumo}

Quantificar as consequências do escoamento superficial e grau de infiltração em bacia urbana permite avaliar o padrão de drenagem dos canais, a ocorrência de enchentes e erosões. O objetivo deste estudo foi estudar a hidromorfologia da bacia hidrográfica urbana do córrego Botafogo visando quantificar os parâmetros físicos e morfológicos que interferem no seu comportamento hidrológico. A metodologia utilizada no estudo foi o emprego de equações numéricas, além dos dados raster e vetoriais gerados em programa SIG, favorecendo a investigação dos parâmetros de linearidade, área, comprimento e hipsometria da bacia, revelando, assim, o comportamento da fisiografia da bacia e indicando os índices morfológicos que interferem na sua atividade hidrológica. As enchentes no Córrego Botafogo têm sido frequentes em decorrência do gradiente altimétrico $(143 \mathrm{~m})$ do corpo hídrico que nasce na cota $844 \mathrm{~m}$ e deságua na altitude de $701 \mathrm{~m}$ em relação ao nível do mar, indicando um relevo com pouco declive que contribui para a rápida concentração das águas de chuva no Córrego Botafogo e nos seus afluentes. A bacia do Córrego Botafogo é mal drenada $\left(0,58 \mathrm{~km}^{-1}\right)$, sugerindo portanto que a ocorrência de alagamentos tem relação com o relevo.

Palavras-chave: Bacia hidrográfica; Hipsometria; Fisiografia

\section{Abstract}

Quantifying the consequences of runoff and degree of infiltration in an urban basin allows the assessment of channel drainage patterns, the occurrence of floods and erosion. The objective of this study was to study the hydromorphology of the urban watershed of the Botafogo Stream, aiming to quantify the physical and morphological parameters that interfere in its hydrological behavior. The methodology used in the study was the use of numerical equations, in addition to the raster and vector data generated in the GIS program, favoring the investigation of the parameters of linearity, area, length and hypsometry of the basin, revealing the behavior of the physiography of the river basin and indicating the morphological indices that interfere in its hydrological activity. Floods in the Botafogo Stream have been frequent due to the altimetric gradient $(143 \mathrm{~m})$ of the water body that is born at quota 844 and flows at an altitude of $701 \mathrm{~m}$ in relation to the level of the sea, indicating a slight slope that contributes to the rapid concentration of rainwater in the Botafogo Stream and its tributaries. The Botafogo River Basin is poorly drained $\left(0.58 \mathrm{~km}^{-1}\right)$ suggesting, therefore, that the occurrence of floods is related to the relief.

Keywords: River basin; Hypsometry; Physiography 


\section{Introdução}

A vulnerabilidade dos solos à poluição e contaminação, desencadeada pelo uso e ocupação inadequados das áreas, compromete a qualidade e a quantidade de água disponível para consumo em razão das características hidrogeológicas da zona do aquífero, bem como do tipo de poluente/contaminante e da velocidade do fluxo (PINTO et al., 2004). Além disso, a urbanização de bacias interfere nos processos hidrológicos das respectivas áreas em virtude da exaustão dos aquíferos e das fontes poluidoras advindas das práticas domésticas e industriais, sejam por meio de infiltração de efluentes, chorume, fertilizantes, problemas construtivos ou hidráulicos (TUCCI; HESPANHOL; CORDEIRO NETO, 2000).

Nas áreas urbanas, as fontes mais frequentes de poluição são provenientes de postos de gasolina: combustíveis líquidos, solventes aromáticos, hidrocarbonetos aromáticos policíclicos (PAH), metais pesados e solventes halogenados (HIRATA et al., 2006), sugerindo, portanto, que o desenvolvimento econômico está intrinsecamente relacionado com os impactos ambientais em bacias urbanas, vide maior impermeabilização do solo decorrente da pavimentação de ruas e edificações em áreas urbanas, concentração de poços e vazões bombeadas, bem como o aumento do desmatamento e compactação do solo, reduzindo a infiltração e respectiva recarga dos aquíferos, aumentando a velocidade e o volume de escoamento superficial, acarretando inundações, processos erosivos e assoreamento das drenagens superficiais (GOIÁS, 2006).

Partindo da premissa que a água é um recurso renovável e limitado, destacando ainda as pressões antrópicas inerentes ao desenvolvimento econômico que comprometem a qualidade e a quantidade hídrica disponível, soluções alternativas de uso da água, bem como a reavaliação dos padrões de comportamento humano, precisam ser abordadas, mediante estudo da topografia local, com levantamento planialtimétrico e informações geológicas da área de interesse, no intuito de identificar camadas permeáveis, impermeáveis, regiões de recarga e descarga, bem como os tipos de aquíferos existentes. Santana et al. (2007) destacam a necessidade em ser efetivado um plano de ação que oriente o uso e manejo de áreas cuja incidência das forças antrópicas tem acarretado esgotamento dos mananciais superficiais de abastecimento e consequente agravamento da explotação de mananciais subterrâneos.

Conforme corroborado por White et al. (2013), quantificar as consequências do escoamento superficial e grau de infiltração da bacia decorrente do processo de urbanização permite avaliar o padrão de drenagem dos canais, a ocorrência de enchentes e erosões a degradação ambiental dos recursos hídricos e o grau de explotação das águas subterrâneas. Programas que possuem estrutura em SIG (Sistema de Informação Geográfica) têm capacidade de armazenamento, manipulação e análise de dados geográficos permitindo o cruzamento destes e a estimativa de cenários futuros, favorecendo o planejamento territorial e a gestão do meio ambiente, especialmente a gestão de bacias hidrográficas e constituem ferramentas eficientes para espacialização e regionalização de bacias (CARDOSO e MARCUZZO, 2011).

O objetivo desta pesquisa foi estudar a hidromorfologia da bacia hidrográfica urbana do córrego Botafogo visando quantificar os parâmetros físicos e morfológicos que interferem no seu comportamento hidrológico e na interação entre água e solo da bacia, a fim de disponibilizar dados fisiográficos que fomentem o uso e ocupação da área de forma sustentável e segura, uma vez que a zona de amortecimento da bacia encontra-se consideravelmente antropizada. 


\section{Materiais}

\subsection{Localização da Bacia Hidrográfica do Córrego Botafogo}

Geograficamente, a bacia do Córrego Botafogo localiza-se entre os paralelos 682852 e 688852 e meridianos 8145843 e 8165843 , abrangendo os municípios de Goiânia e Aparecida de Goiânia da região centro-oeste do Brasil, Estado de Goiás. Trata-se de uma sub-bacia do Ribeirão Anicuns (Figura 1) que se encontra em sua totalidade inserida nos núcleos urbanos dos municípios supracitados, contemplando os seguintes bairros: Jardim das Esmeraldas, Bairro Santo Antônio, Vila Maria José, Vila São João, Vila Redenção, Pedro Ludovico, Jardim Goiás, Setor Sul, Setor Central, Setor Leste Universitário, Setor Vila Nova, Setor Leste, Setor Norte Ferroviário, Setor Criméia Leste e Setor Criméia Oeste (MARTINS JÚNIOR, 1996).

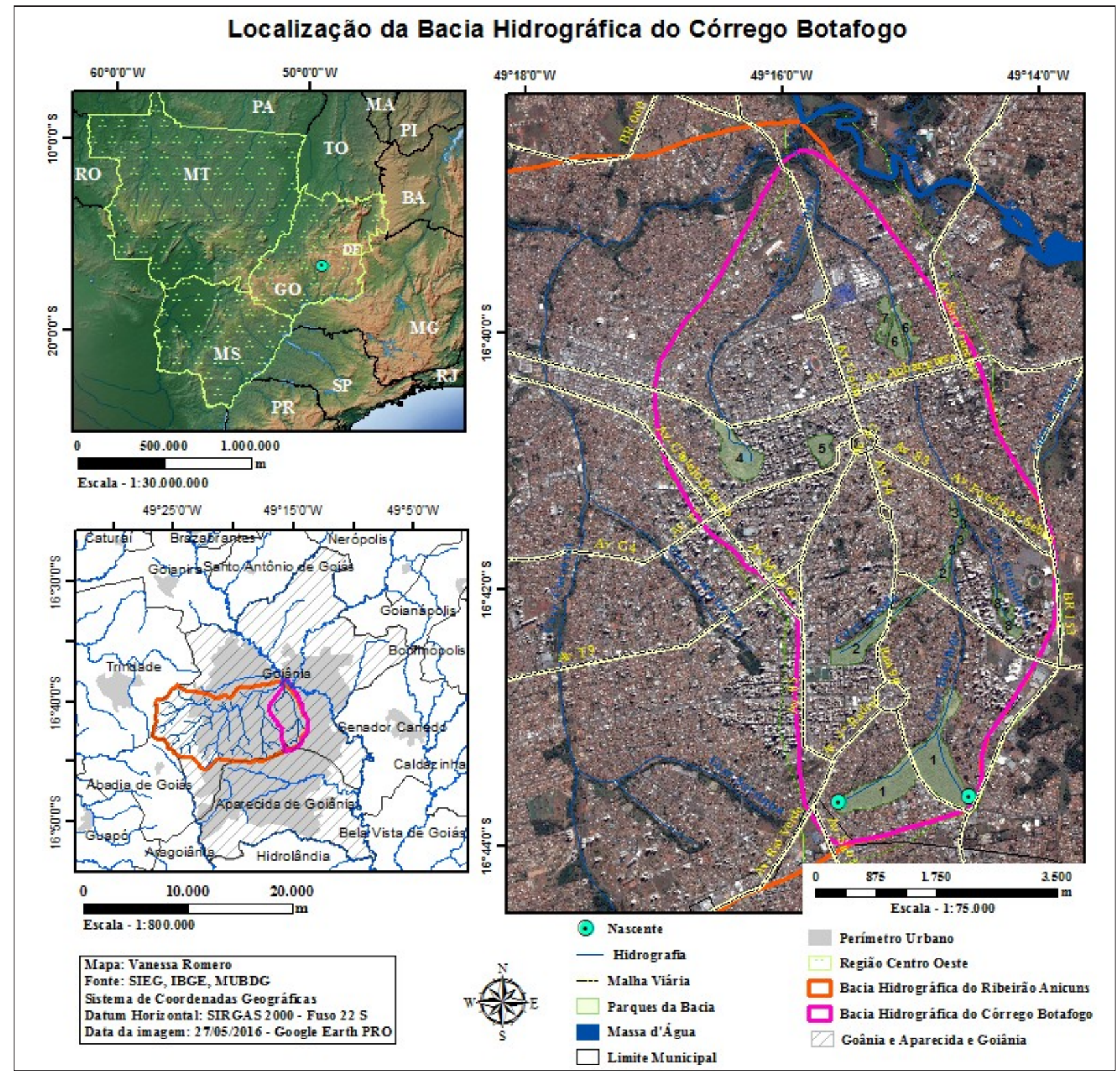

Figura 1 - Mapa de Localização da Bacia Hidrográfica do Córrego Botafogo

Fonte - Fonte: Elaborado pelos autores com dados do SIEG (2014), IBGE (2010) e MUBDG (2015) 
2.2. Bioma, Clima, Densidade Demográfica, Altimetria e Declividade da Bacia Hidrográfica do Córrego Botafogo

O bioma cerrado contempla toda a cidade de Goiânia e Aparecida de Goiânia, consequentemente abrangendo toda a área da bacia hidrográfica do Botafogo (MARCUZZO; ROMERO; CARDOSO, 2014). Segundo a classificação climática de Köppen, existem três climas atuantes no estado de Goiás: o clima tropical com estação seca no inverno (Aw), o clima temperado úmido com inverno seco e verão quente (Cwa) e o clima temperado úmido com inverno seco e verão temperado $(\mathrm{Cwb})$, conferindo à região a predominância de dois períodos no ano: seco e chuvoso (Aw) (PEEL; FINLAYSON; MCMAHON, 2007). O clima na capital Goiânia é o tropical semiúmido, com período seco no outono e inverno (maio a setembro) e período chuvoso na primavera e verão (outubro a abril) (SILVA JÚNIOR et al., 2011).

Conforme dados censitários do IBGE (2010), a cidade de Goiânia possui em média 1.302.001 habitantes, sendo que cerca de $70 \%$ da população vive nos limites da bacia do ribeirão Anicuns (GOIÂNIA, 2008). A importância da área de pesquisa é evidente quando consideramos que mais de 911.400 pessoas habitam a região, convivendo, contribuindo e suportando os problemas socioambientais ali existentes.

A declividade da bacia hidrográfica do córrego Botafogo vai de $0 \%$ a 56,38\% (Figura 2) em uma área de aproximadamente $32,84 \mathrm{~km}^{2}$, sendo a extensão do principal corpo hídrico da bacia hidrográfica, o córrego Botafogo, com aproximadamente 10,93 km (da nascente ao exutório, no ribeirão Anicuns) (Figura 2).

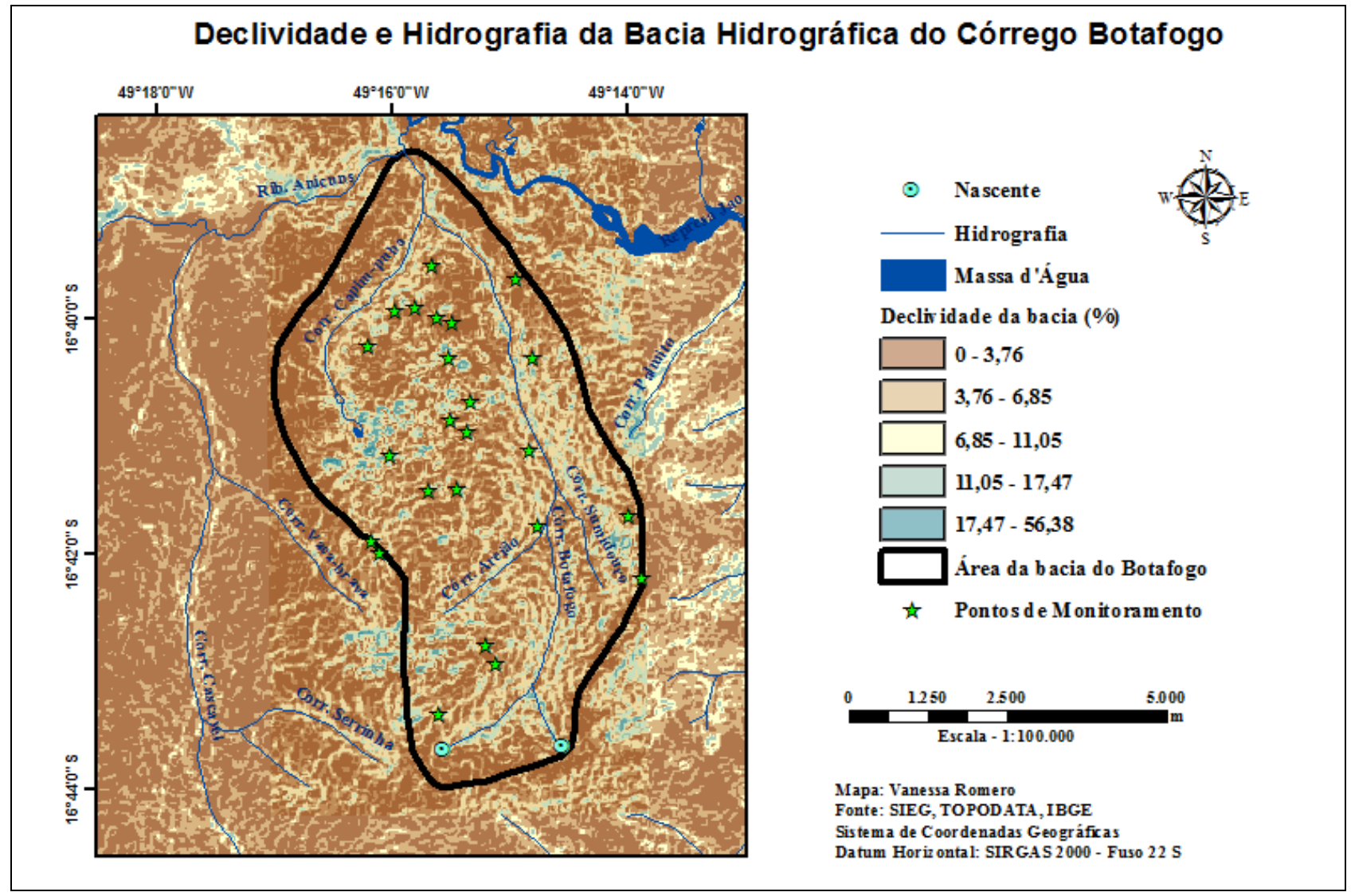

Figura 2 - Mapa de Declividade e Hidrografia da Bacia do Córrego Botafogo

Fonte - Elaborado pelos autores com dados do SIEG (2014), da USGS (2002) e do IBGE (2010)

Dados do projeto SRTM (Shuttle Radar Topographic Mission) disponibilizados pelo Serviço Geológico dos Estados Unidos (2016), da sigla em inglês USGS, foram agrupados em um programa de SIG (Sistema de Informações 
Geográficas), mediante utilização de imagens de radar com resolução de 30 metros, visando estabelecer os limites da bacia hidrográfica do Córrego Botafogo (Figura 3), com MDE (Modelo Digital de Elevação) posteriormente delimitado permitindo analisar sua hipsometria, cuja amplitude altimétrica varia de 690 a 892 metros (Figura 3).

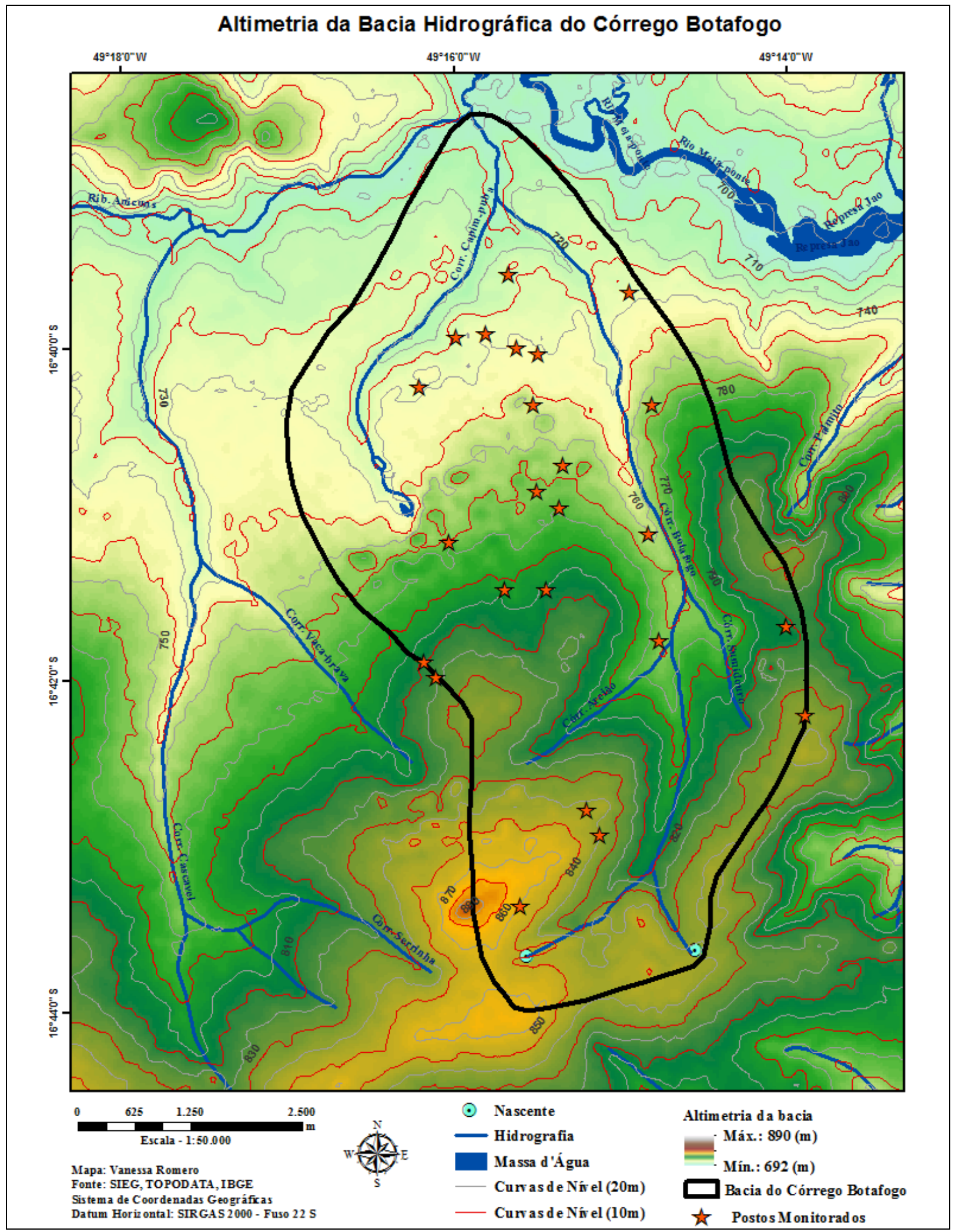

Figura 3 - Mapa da Altimetria da Bacia do Córrego Botafogo

Fonte - Elaborado pelos autores com dados do SIEG (2014), USGS (2002) e do IBGE (2010) 


\subsection{Uso e Ocupação do Solo na Área da Bacia do Córrego Botafogo}

O córrego Botafogo é o principal corpo hídrico da bacia, possui duas nascentes no Jardim Botânico, exutório no rio Meia-Ponte e três subafluentes: pela margem direita, o córrego Sumidouro, e pela margem esquerda, os córregos Areião e Capim-Puba. Na área de abrangência da bacia hidrográfica do Botafogo encontram-se pequenas porções dispersas de vegetação remanescente, e, pequena porção acima do norte da bacia caracteriza-se pela prática da agricultura. A área de estudo encontra-se consideravelmente antropizada, vide uso e ocupação inadequada da zona de amortecimento da bacia que se caracteriza pela ocupação de habitações irregulares, centros comerciais, além de ruas pavimentadas ao longo da canalização do córrego Botafogo (Figura 4).

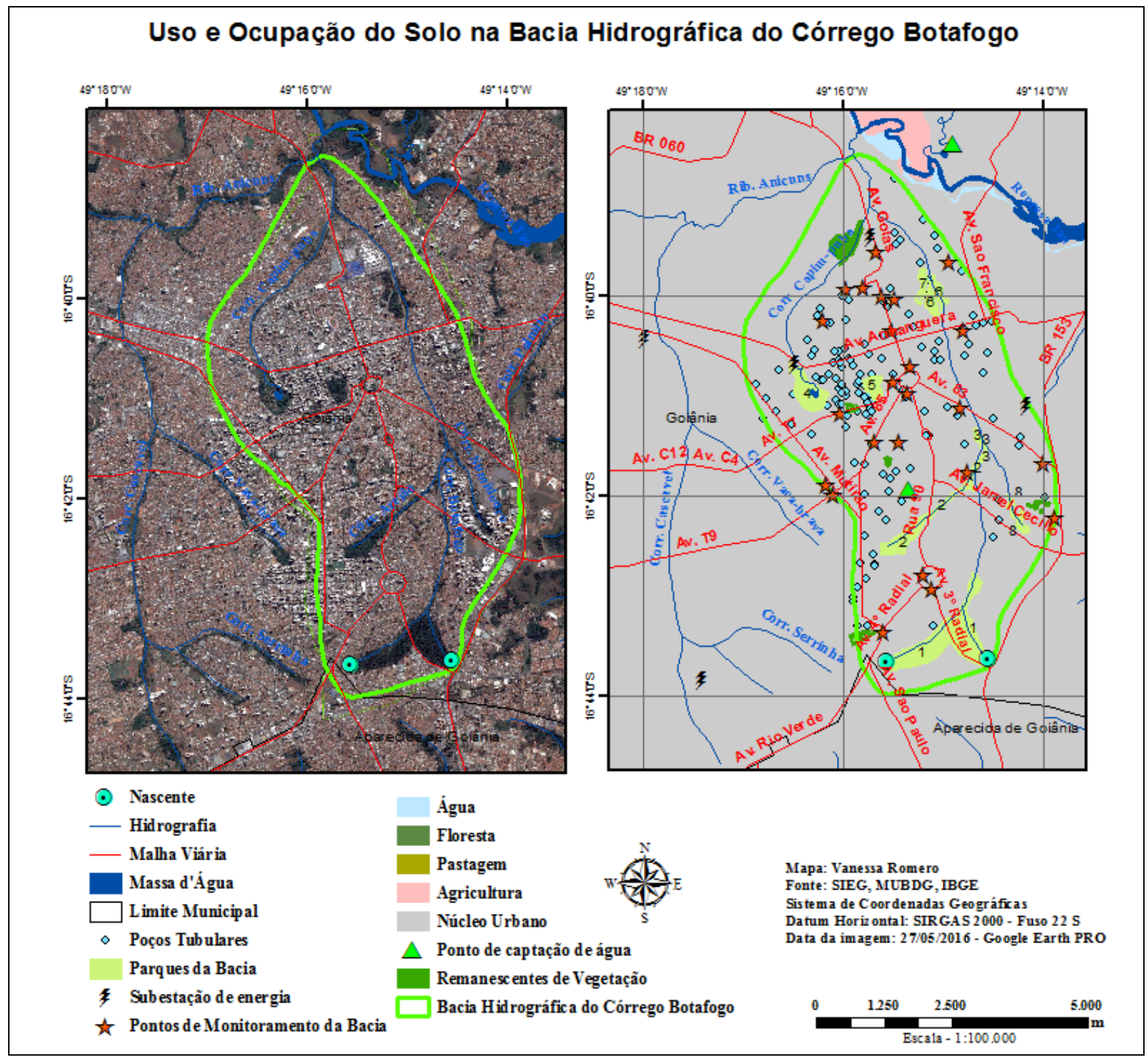

Figura 4 - Uso e Ocupação do Solo na Bacia do Córrego Botafogo

Fonte - Elaborado pelos autores com dados do Google Earth PRO (2016), SIEG (2014), MUBDG (2015) e IBGE (2010)

De acordo com a base cartográfica utilizada existem 174 poços tubulares devidamente cadastrados e/ou outorgados instalados na bacia, além de 3 subestações de energia e 8 parques: Jardim Botânico (1), Areião (2), Linear do Botafogo (3), Zoológico (4), Buritis, (5), Botafogo (6), Mutirama (7) e Flamboyant (8) (Figura 4). 


\subsection{Pedologia, Geomorfologia e Sistema Aquífero da Bacia do Córrego Botafogo}

Identifica-se na macrozona de Goiânia domínios pedológicos do tipo Latossolo Vermelho Escuros (mapeados na porção norte da área), Latossolo de natureza areno-argiloso Vermelho-Amarelado a Amarelado (observados na porção sul da área); Litossolos e Gleissolos/podzólicos (solos aluviais do tipo glei, húmicos, encontados, geralmente, ao longo do canal dos córregos que drenam esta macrozona) (GOIÂNIA, 2008).

A geomorfologia é um dos aspectos mais relevantes para estudos hidrológicos pois permite avaliar como cada unidade geomorfológica influencia as condições de circulação das águas subterrâneas e de potencial de recarga e descarga de aquíferos, conforme o padrão de relevo, hipsometria, densidade de drenagem e tipos de coberturas de regolito. As áreas mais elevadas favorecem a recarga de aquífero por apresentarem maior gradiente e em geral maior carga hidráulica em aquíferos regionais que favorecem as condições de infiltração e transferência das águas de precipitação para zonas mais profundas dos aquíferos. Ademais, áreas consideradas de dissecação muito fraca compõe as melhores zonas de recarga e áreas com dissecação muito forte compõem regiões com baixo potencial de recarga (GOIÁS, 2006).

Segundo Casseti (1992) o método de fotointerpretação de aerofotos escalonadas em 1:40.000 possibilitou a distinção de cinco unidades morfológicas no município de Goiânia, conforme Quadro 1.

Quadro 1 - Unidades Morfológicas do município de Goiânia

\begin{tabular}{|c|c|c|c|c|}
\hline Unidade & $\begin{array}{l}\text { Altitude } \\
\text { (m) }\end{array}$ & Características Gerais & Subunidades & Região \\
\hline \multirow{2}{*}{$\begin{array}{l}\text { Planalto Dissecado } \\
\text { de Goiânia }\end{array}$} & \multirow{2}{*}{$\begin{array}{l}920 \quad \mathrm{a} \\
950\end{array}$} & Elevado grau de dissecação & $\begin{array}{l}\text { Superficies de Formas Aguçadas (declives } \\
\text { superiores a } 30 \% \text { ) }\end{array}$ & $\mathrm{Ne} \mathrm{NE}$ \\
\hline & & Forte gradiente & $\begin{array}{l}\text { Superficies de Formas Convexas (declives } \\
\text { inferiores a } 20 \% \text { ) }\end{array}$ & Morro do Mendanha \\
\hline \multirow{2}{*}{$\begin{array}{l}\text { Chapadões de } \\
\text { Goiânia }\end{array}$} & \multirow{2}{*}{$\begin{array}{ll}860 & \mathrm{a} \\
900 & \end{array}$} & $\begin{array}{l}\text { Fluxo laminar, transporte de sedimentos, } \\
\text { entulhamento }\end{array}$ & Superfície Aplainada & \multirow{2}{*}{$\mathrm{SO}$} \\
\hline & & $\begin{array}{l}\text { Fluxo laminar concentrado, ravinamentos, } \\
\text { erosão, solos permeáveis }\end{array}$ & Superfícies Rampeadas & \\
\hline \multirow{2}{*}{$\begin{array}{l}\text { Planalto Embutido } \\
\text { de Goiânia }\end{array}$} & \multirow{2}{*}{$\begin{array}{ll}750 & \mathrm{a} \\
800 & \end{array}$} & $\begin{array}{l}\text { Impermeabilização do solo, concentração } \\
\text { de enxurradas. }\end{array}$ & $\begin{array}{l}\text { Superficies de Formas Convexas (declives } \\
\text { suaves até } 10 \% \text { e moderados até } 20 \% \text { ) }\end{array}$ & \multirow{2}{*}{$\begin{array}{lrr}\text { Entre o } & \text { Planalto } \\
\text { Dissecado } & \text { e } & \text { os } \\
\text { Chapadões } & & \text { de } \\
\text { Goiânia } & & \end{array}$} \\
\hline & & Apto à ocupação urbana & $\begin{array}{l}\text { Superficies de Formas Tabulares (declives até } \\
10 \% \text { predominando as áreas de declividade } \\
\text { entre } 0 \text { e } 5 \% \text { ) }\end{array}$ & \\
\hline \multirow{2}{*}{$\begin{array}{l}\text { Terraços e Planícies } \\
\text { da Bacia do Rio } \\
\text { Meia Ponte }\end{array}$} & \multirow{2}{*}{$\begin{array}{l}700 \quad \mathrm{a} \\
720\end{array}$} & $\begin{array}{l}\text { Fluxo laminar, cascalheiras sotopostas, } \\
\text { sequências alúvio-coluvionares }\end{array}$ & Terraços Fluviais Suspensos & \\
\hline & & $\begin{array}{l}\text { Sedimentos arenosos, sequências silto- } \\
\text { argilosas, enchentes de verão }\end{array}$ & Planícies Fluviais de Inundação & $\begin{array}{l}\text { Rio Meia-Ponte, } \\
\text { Ribeirões João } \\
\text { Leite, Anicuns e } \\
\text { Capivara }\end{array}$ \\
\hline Fundos de Vale & - & Erosão acelerada, ravinas ou voçorocas & $\begin{array}{l}\text { Faixas de transição entre os processos com } \\
\text { declives podendo ultrapassar } 40 \%\end{array}$ & $\begin{array}{l}\text { Ao longo de toda a } \\
\text { drenagem }\end{array}$ \\
\hline
\end{tabular}


Cunha (2000) destaca a importância dessas formações superficiais cenozoicas que, além de condicionarem o abastecimento dos freáticos livres, também possibilitam o desenvolvimento de diversificada vegetação, responsável pela existência e manutenção da fauna e pela redução dos processos erosivos. $\mathrm{O}$ autor enfatiza ainda que as formações superficiais representam a base para os processos de produção do espaço, servindo como fonte para a produção tecnogênica, além de testemunharem os diferentes graus de intensidade da ação antrópica.

A bacia do córrego Botafogo encontra-se inserida no Sistema Freático II (Figura 6), característico sistema aquífero raso que inclui todas as classes de Latossolos e, portanto, "é o sistema de maior expressão areal no estado de Goiás" (GOIÁS, 2006).

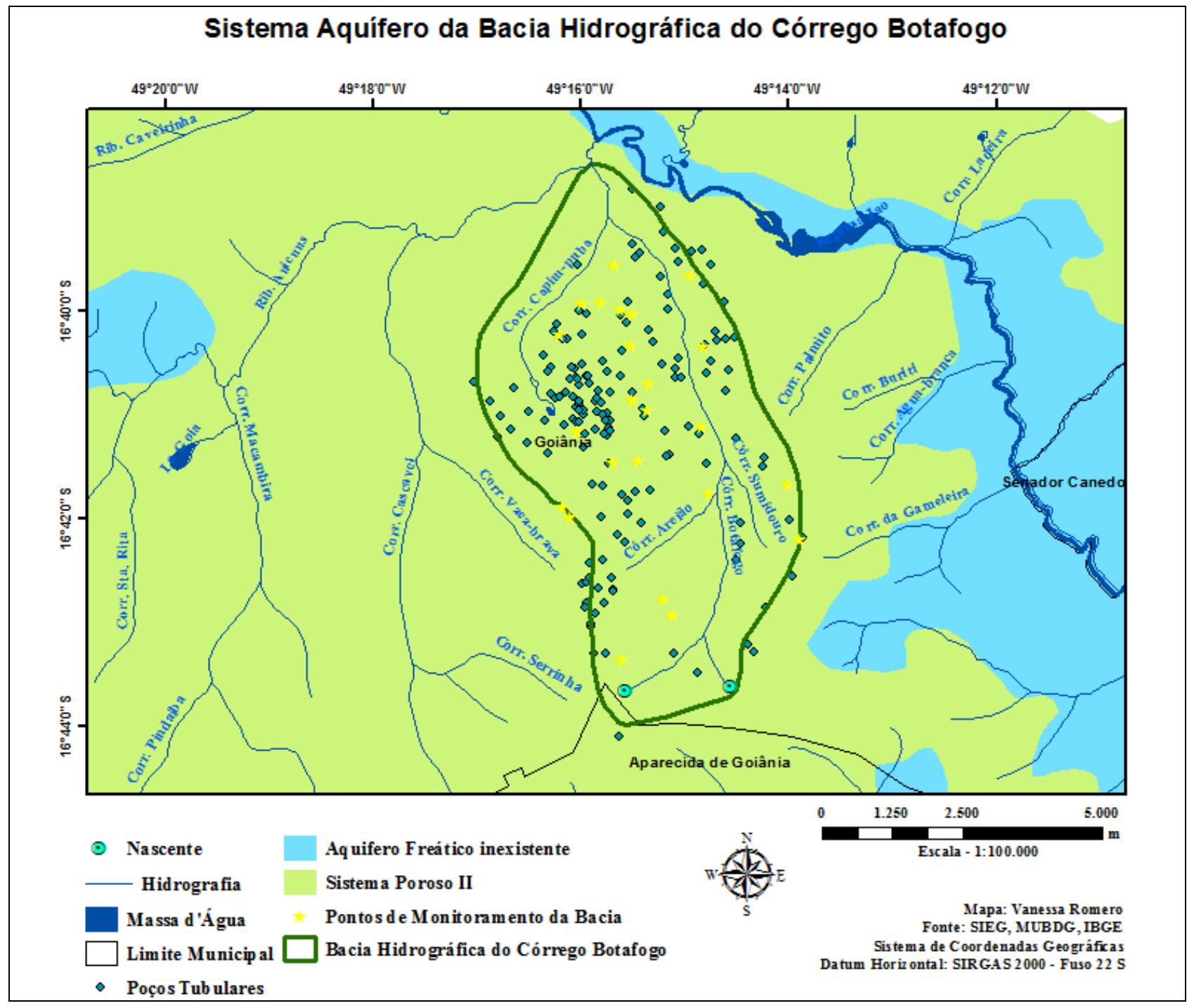

Figura 6 - Mapa do Sistema Aquífero da Bacia Hidrográfica do Córrego Botafogo

Fonte - Elaborado pelos autores com dados do SIEG (2014), MUBDG (2015) e IBGE (2010)

O sistema aquífero da bacia do Botafogo, portanto, encontra-se fortemente vinculado às Superfícies Regionais de Aplainamento - SRA, que se caracterizam pelo padrão de relevo suave ondulado a plano, cuja estrutura granular dos latossolos, independente de textura (muito argilosa, argilosa, franca, siltosa, etc.), imprimem um funcionamento hídrico de alta condutividade hidráulica e elevada porosidade efetiva (não inferior a 8\%) (GOIÁS, 2006). No trabalho 
desenvolvido por Machado e Marcuzzo (2015) os autores relatam que as regiões de maior pluviosidade na bacia estão associadas com áreas de relevos elevados, suportados por litologias granulíticas, graníticas, gnáissicas e xistosas, pouco fraturadas e localmente com pequena cobertura de alteração. Como as rochas sedimentares são compostas principalmente por pelíticas, os valores de recarga são bastante baixos. Os mesmos autores relatam que a sub-bacia 83 caracteriza-se por possuir zonas aquíferas com produtividade que varia de média à baixa. Cidades importantes da bacia hidrográfica como Blumenau e Rio do Sul possuem aquíferos com vazões explotáveis que raramente ultrapassam a 20 $\mathrm{m}^{3} \cdot \mathrm{h}^{-1}$, sendo alternativa inviável ao abastecimento público. Os poços tubulares geralmente são rasos (100 a 150m) não existindo melhores condições hidrogeológicas em maiores profundidades.

\section{Metodologia}

A metodologia utilizada para o estudo morfológico da bacia hidrográfica objeto da pesquisa foi o emprego de equações numéricas, além de dados raster e vetoriais gerados em programa SIG, favorecendo a investigação de parâmetros tais como linearidade, área, comprimento e hipsometria de bacia hidrográfica, segundo proposta de Horton (1945), revelando, assim, o comportamento da fisiografia da bacia e indicando os índices morfológicos que interferem na sua atividade hidrológica. Tschiedel et al. (2012), Marcuzzo et al. (2011; 2012), Melati e Marcuzzo (2015), Goularte et al. (2013; 2016), Pinto Filho et al. (2011), Cardoso et al. (2011) e Romero et al. (2011) utilizam as fórmulas apresentadas a seguir:

\subsection{Metodologia para Estudo Linear}

\subsubsection{Relação de bifurcação $(\mathrm{Rb})$}

A relação de Bifurcação foi definida por Horton (1945) como sendo a relação entre o número total de segmentos de certa ordem e o número total dos de ordem imediatamente superior.

$R b=\frac{N u}{N u+1}$

Em que:

$\mathrm{Nu}=$ número de segmentos de determinada ordem;

$\mathrm{Nu}+1=$ número de segmentos da ordem imediatamente superior.

\subsection{2. Índice de sinuosidade (Is)}

O índice de sinuosidade é a relação entre a distância da desembocadura do rio e a nascente mais distante (equivalente vetorial), medida em linha reta $(E v)$, e o comprimento do canal principal $(L)$. O índice de sinuosidade possui classes, divididas conforme o Quadro 2.

$I s=\frac{100(L-E v)}{L}$

Em que:

Is = índice de sinuosidade;

$\mathrm{L}=$ comprimento do canal principal $(\mathrm{km})$;

$\mathrm{Ev}=$ equivalente vetorial $(\mathrm{km})$. 
Quadro 2 - Índices de sinuosidade divididos por classes

\begin{tabular}{|c|c|c|}
\hline Classe & Descrição & Limites (\%) \\
\hline I & Muito reto & $<20$ \\
\hline II & Reto & 20 a 29 \\
\hline III & Divagante & 30 a 39,9 \\
\hline IV & Sinuoso & 40 a 49,95 \\
\hline V & Muito sinuoso & $>50$ \\
\hline
\end{tabular}

3.1.3. Relação entre o comprimento médio dos canais de cada ordem

Para se calcular o comprimento médio dos segmentos fluviais, divide-se a soma dos comprimentos dos canais de cada ordem pelo número de segmentos encontrados na respectiva ordem.

$L m=\frac{L u}{N u}$

Em que:

$\mathrm{Lm}=$ comprimento médio dos segmentos fluviais $(\mathrm{km})$;

$\mathrm{Lu}=$ soma dos comprimentos dos canais de cada ordem $(\mathrm{km})$;

$\mathrm{Nu}=$ número de segmentos encontrados na respectiva ordem.

3.1.4. Comprimento do canal principal

É a distância que se estende ao longo do curso d'água desde a nascente principal até a desembocadura (Foz).

3.1.5. Equivalente vetorial do canal principal (Ev)

O equivalente vetorial representa o comprimento de cada segmento fluvial de determinada ordem, em linha reta, que se estende do nascimento ao término do referido canal.

\section{Ev $=$ distância em $\mathrm{km}$}

Nascente $\rightarrow$ Foz

3.1.6. Extensão do percurso superficial (Eps)

Representa a distância média percorrida pelas enxurradas entre o interflúvio e o canal permanente, correspondendo a uma das variáveis independentes mais importantes que afeta tanto o desenvolvimento hidrológico como fisiográfico das bacias de drenagem. Durante a evolução do sistema de drenagem, a extensão do percurso superficial está ajustada ao tamanho apropriado relacionado com as bacias de primeira ordem, sendo aproximadamente igual à metade do recíproco valor da densidade de drenagem.

Eps $=\frac{1}{2 D d}$

Em que:

Eps $=$ extensão do percurso superficial $\left(\mathrm{km}^{-1}\right)$.

$\mathrm{Dd}=$ valor da densidade de drenagem. 


\subsubsection{Gradiente dos canais}

Vem a ser a relação entre a diferença máxima de altitude entre o ponto de origem e o término com o comprimento do respectivo segmento fluvial. A sua finalidade é indicar a declividade dos cursos de água, podendo ser medido para o rio principal e para todos os segmentos de qualquer ordem.

\section{Alt. Max - Alt.. in $=$ Gradiente do canal}

Em que:

Alt. Max = altitude máxima;

Alt. Max = altitude mínima.

\subsection{Metodologia para Estudo Areal}

\subsection{1. Área da bacia $(\mathrm{A})$}

É toda área determinada normalmente $\mathrm{em}^{\mathrm{k}}{ }^{2}$, drenada pelo conjunto do sistema fluvial, projetada em plano horizontal. Determinando o perímetro da bacia, a área pode ser calculada com o auxílio do planímetro, de papel milimetrado, pela pesagem de papel uniforme devidamente recortado ou através de técnicas mais sofisticadas, com o auxílio do computador (CHRISTOFOLETTI, 1980).

\subsubsection{Relação entre o comprimento do rio principal e área da bacia}

Esta fórmula demonstra notável consistência entre os dados, apesar da diversidade de condições ambientais envolvidas, permitindo que o comprimento geométrico do curso de água principal possa ser calculado conforme a seguinte expressão, proposta inicialmente por Christofoletti (1980).

$L=1,5 A^{0,6}$

Em que:

$\mathrm{L}=$ comprimento do canal principal $(\mathrm{m})$;

$\mathrm{A}=$ área da bacia $\left(\mathrm{m}^{2}\right)$.

\subsubsection{Densidade dos rios (Dr)}

Definido por Horton (1945) apud Christofoletti (1980) é a relação existente entre o número de rios ou cursos de água e a área da bacia hidrográfica. Sua finalidade é comparar a frequência ou a quantidade de cursos de água existentes em uma área de tamanho padrão como, quilômetro quadrado $\left(\mathrm{km}^{2}\right)$.

$D r=\frac{N}{A}$

Em que:

Dr $=$ densidade de rios,

$\mathrm{N}=$ número de rios ou cursos de água,

$\mathrm{A}=$ área da bacia considerada $\left(\mathrm{km}^{2}\right)$. 


\subsubsection{Densidade de drenagem (Dd)}

A densidade de drenagem correlaciona o comprimento total dos canais de escoamento com a área da bacia hidrográfica. A área cuja densidade de drenagem é elevada corresponde à bacia rica em hidrografia, e, inicialmente, definida por Horton (1945) apud Christofoletti (1980) pela equação:

$D d=\frac{L t}{A}$

Em que:

Dd $=$ densidade da drenagem,

$\mathrm{Lt}=$ comprimento total dos canais $(\mathrm{km})$,

$\mathrm{A}=$ área da bacia $\left(\mathrm{km}^{2}\right)$.

\subsubsection{Coeficiente de manutenção $(\mathrm{Cm})$}

Proposto por S. A. Schumm, em (1956), esse índice tem a finalidade de fornecer a área mínima necessária para a manutenção de um metro de canal de escoamento. O referido autor considera-o como um dos valores numéricos mais importantes para a caracterização do sistema de drenagem, podendo ser calculado através de expressão, a fim de que seja significante na escala métrica (CHRISTOFOLETTI, 1980).

$C m=\frac{1}{D d} 1000$

Em que:

$\mathrm{Cm}=$ coeficiente de manutenção,

$\operatorname{Dd}=$ valor da densidade de drenagem $(\mathrm{m})$.

\subsection{Metodologia para Estudo Hipsométrico de Bacia}

\subsubsection{Coeficiente de massividade $(\mathrm{Cm})$ e o Coeficiente orográfico $(\mathrm{Co})$}

É o coeficiente da divisão da altura média $(A m)$ do relevo da área pela superfície $(A)$; e o coeficiente orográfico é a multiplicação da altura média da bacia pelo coeficiente de massividade (CHRISTOFOLETTI, 1980).

$$
\begin{aligned}
& C m=\frac{A m}{A} \\
& C o=A m * C m
\end{aligned}
$$

Em que:

$\mathrm{Cm}=$ coeficiente de massividade $\left(\mathrm{m}^{-1}\right)$,

Am $=$ altura média $(m)$;

$\mathrm{Co}=$ coeficiente orográfico;

$\mathrm{A}=$ área $\left(\mathrm{m}^{2}\right)$. 


\subsubsection{Amplitude altimétrica (Hm)}

Corresponde à diferença altimétrica entre a altitude da desembocadura e a altitude do ponto mais alto situado em qualquer lugar da divisória topográfica. Este conceito é também denominado de "relevo máximo da bacia". No ponto mais elevado deve ser considerada a média das cotas mais elevadas, pois o ponto alto não compreende toda porção mais elevada da bacia hidrográfica (STRAHLER, 1952).

$H m=P 1-P 2$

Em que:

$\mathrm{A}=$ amplitude altimétrica;

$\mathrm{P} 1$ =ponto mais alto $(\mathrm{m})$;

$\mathrm{P} 2$ = ponto mais baixo $(\mathrm{m})$ da bacia hidrográfica.

\subsubsection{Relação de relevo (Rr)}

Considera o relacionamento existente entre a amplitude altimétrica máxima e a maior extensão da bacia hidrográfica medida paralelamente à principal linha de drenagem. A relação do relevo $(R r)$ pode ser calculada dividindo: amplitude topográfica máxima ( $H m$ ) pela raiz quadrada da área da bacia (A) (STRAHLER, 1952).

$R r=\frac{H m}{A^{0,5}}$

Em que:

$\mathrm{Rr}=$ relação de relevo;

$\mathrm{Hm}=$ amplitude topográfica máxima $(\mathrm{m})$;

$\mathrm{A}=$ área da bacia $\left(\mathrm{m}^{2}\right)$.

\subsection{4. Índice de rugosidade (Ir)}

O índice de rugosidade combina as qualidades de declividade e comprimento das vertentes com a densidade de drenagem, expressando-se como número adimensional que resulta do produto entre a amplitude altimétrica e a densidade de drenagem (STRAHLER, 1952).

$I r=H * D d$

Em que:

Ir = relação de relevo;

$\mathrm{Hm}=$ amplitude altimétrica máxima $(\mathrm{m})$;

$\operatorname{Dd}=$ densidade de drenagem $\left(\mathrm{m}^{-1}\right)$.

\section{Resultado e discussões}

Os resultados foram descritos e transpostos em documentos cartográficos (Figuras) visando melhor compreensão do estudo realizado. 


\subsection{Hierarquia Fluvial e Ordem dos Afluentes do Córrego Botafogo}

Strahler (1957) propõe uma ordenação que elimina o conceito de que o rio principal deve ter o mesmo número de ordem em toda a extensão e a necessidade de se refazer a numeração a cada confluência. A Tabela 1 descreve a quantidade de canais de $1^{\mathrm{a}}$ e $2^{\mathrm{a}}$ ordens, os seus respectivos comprimentos $(\mathrm{km})$ e o comprimento médio dos canais por ordem na bacia do Córrego Botafogo.

Tabela - Ordem dos canais, quantidade de canais, comprimento linear e médio por ordem na bacia do Botafogo

\begin{tabular}{lcccc}
\hline & Parâmetro & \multicolumn{2}{c}{ Ordem dos Canais } & \multicolumn{2}{c}{ Total } \\
\cline { 2 - 6 } Quantidade & 3 & $1^{\text {a }}$ & 1 & 4 \\
\hline Comprimento linear & 8,26 & 11,99 & 20,25 \\
\hline Comprimento médio dos canais & 2,75 & 11,99 & 14,74 \\
\hline
\end{tabular}

\subsection{Análise Linear da Rede Hidrográfica da Bacia do Córrego Botafogo}

\subsubsection{Comprimento do canal principal}

No cálculo do canal principal foi considerado o curso d'água principal que percorria a maior distância entre a nascente e sua respectiva foz. O Córrego Botafogo possui aproximadamente 10,93 km de extensão (Tabela 2).

Tabela 2 - Comprimento dos canais por ordem na bacia do Córrego Botafogo

\begin{tabular}{|c|c|c|c|}
\hline \multirow{2}{*}{ Curso d'água } & \multicolumn{2}{|c|}{ Comprimento (km) } & \multirow{2}{*}{ Ordem } \\
\hline & Nascente 1 & Nascente 2 & \\
\hline Córrego Botafogo & 10,93 & 10,28 & $2^{\mathrm{a}}$ \\
\hline Córrego Sumidouro & \multicolumn{2}{|r|}{1,8} & $1^{\mathrm{a}}$ \\
\hline Córrego Areião & \multicolumn{2}{|r|}{2,08} & $1^{\mathrm{a}}$ \\
\hline Córrego Capim-Puba & \multicolumn{2}{|r|}{4,37} & $1^{\mathrm{a}}$ \\
\hline
\end{tabular}

\subsubsection{Relação entre o comprimento médio dos canais de cada ordem}

O cálculo da relação entre o comprimento médio dos cursos d'água de cada ordem da bacia do Córrego Botafogo (Tabela 3) mostrou que há uma correlação decrescente com o aumento da ordem e do comprimento médio dos cursos d'água.

Tabela 3 - Relação entre o comprimento médio dos cursos d'água (LM) de cada ordem da bacia do Córrego Botafogo

\begin{tabular}{ccclll}
\hline & Ordem & Quantidade & \% & km & Lm \\
\hline & 1 & 3 & 75 & 8,25 & 2,75 \\
& 2 & 1 & 25 & 10,93 & 10,93 \\
\hline Total & & 4 & 100 & 19,18 & 13,68 \\
\hline
\end{tabular}

\subsubsection{Análise da relação de bifurcação, índice de sinuosidade e equivalente vetorial dos canais da bacia}

Estudando o sistema de ordenação de Strahler (1952), Christofolleti (1980) concluiu que o resultado obtido na relação de bifurcação nunca pode ser inferior a 2, devendo, normalmente, variar entre 3 e 5 . Segundo Machado e Souza (2005), o índice de bifurcação trata-se de um parâmetro que favorece a análise das características do substrato rochoso 
quanto à permeabilidade e ao escoamento superficial, de modo que os índices mais elevados imprimem aos substratos menor infiltração de água pluvial e maior escoamento superficial e, os índices menores, maior permeabilidade e menor escoamento superficial.

Ao passo que o índice de sinuosidade é de grande relevância para a análise dos cursos d'água, pois ele determina se o canal é formado por reta ou possui elevada sinuosidade.

Na bacia do Córrego Botafogo a relação de bifurcação foi de 1 (Tabela 4). O Córrego Botafogo possui 14,27\% de sinuosidade ficando na classe I, conforme o Quadro 2 (item 3.1.- Metodologia para o estudo de linearidade da bacia), sendo considerado muito reto, ou seja, não possui áreas acentuadamente sinuosas no decorrer do seu percurso.

O cálculo do equivalente vetorial do curso d'água principal tem um valor interpretativo, pois resulta de seu confronto com os índices do comprimento médio e da declividade média. Christofoletti (1980) cita que nos canais retilinizados e com alta declividade, a grandeza do equivalente vetorial aproxima-se do comprimento, detendo por isso, menor percurso.

$\mathrm{Na}$ bacia do Córrego Botafogo verifica-se que a diferença deste curso d'água $(10,93 \mathrm{~km})$ e o parâmetro equivalente vetorial $(9,37 \mathrm{~km}$ ) (Tabela 4) resulta em 1,56 km. Este dado mostra o distanciamento da nascente do curso d'água até sua foz correspondendo ao controle morfométrico da bacia hidrográfica do Córrego Botafogo.

\subsubsection{Extensão do percurso superficial}

A extensão do percurso superficial é uma relação que é dependente da extensão que o fluxo terá que percorrer desde o interflúvio da bacia até o talvegue. A extensão do percurso superficial foi de 0,86 km-1 (Tabela 4), que, de acordo com a literatura em média, a cada distância de $0,86 \mathrm{~km}$ na vertente haverá um canal para escoamento das águas superficiais da bacia do Córrego Botafogo.

Tabela 4 - Análise Linear da Bacia do Córrego Botafogo

\begin{tabular}{lcccc}
\hline \multicolumn{1}{c}{ Parâmetros } & Córrego Botafogo & Córrego Sumidouro & Córrego Areião & $\begin{array}{c}\text { Córrego Capim- } \\
\text { Puba }\end{array}$ \\
\hline Relação de bifurcação & - & 1 & 1 & 1 \\
\hline Índice de sinuosidade (\%) & 14,27 & 3,33 & 0,96 & 16,25 \\
\hline Comprimento $(\mathrm{km})$ & 10,93 & 1,8 & 2,08 & 4,37 \\
\hline Comprimento médio dos canais $(\mathrm{km})$ & 10,93 & 2,75 & 2,75 & 2,75 \\
\hline Equivalente vetorial $(\mathrm{km})$ & 9,37 & 1,74 & 2,06 & 3,66 \\
\hline Extensão do percurso superficial $\left(\mathrm{km}^{-1}\right)$ & 0,86 & 0,86 & 0,86 & \\
\hline
\end{tabular}

\subsubsection{Gradiente do canal}

O cálculo do gradiente altimétrico do curso d'água é feito pela diferença altimétrica entre a nascente do rio e sua respectiva foz. A principal nascente do Córrego Botafogo está próxima do nível $844 \mathrm{~m}$ e sua foz a $701 \mathrm{~m}$ do nível do mar, seu gradiente altimétrico é de $143 \mathrm{~m}$ distribuídos em 10,93 km de extensão do canal principal. Na Tabela 5 consta o gradiente altimétrico dos cursos d'água formadores da bacia do Córrego Botafogo. 
Tabela 5 - Gradiente dos rios da bacia do Córrego Botafogo

\begin{tabular}{|c|c|c|c|c|}
\hline \multirow{2}{*}{ Curso d'água } & \multicolumn{2}{|c|}{ Altitude (m) } & \multirow{2}{*}{ Gradiente (m) } & \multirow{2}{*}{ Comprimento $(\mathrm{km})$} \\
\hline & Nascente & Foz & & \\
\hline Córrego Botafogo & 844 & 701 & 143 & 10,93 \\
\hline Córrego Sumidouro & 818 & 765 & 53 & 1,8 \\
\hline Córrego Areião & 827 & 765 & 62 & 2,08 \\
\hline Córrego Capim-Puba & 740 & 703 & 37 & 4,37 \\
\hline
\end{tabular}

\subsection{Análise Areal da Bacia do Córrego Botafogo}

\subsection{1. Área e perímetro da bacia}

Entende-se por área de bacia hidrográfica como toda região drenada pelo mesmo conjunto de canais livres naturais ou não, sendo os seus limites delimitados pelos divisores d'água (interflúvios; divisores de drenagem). Os cursos d'água delimitados dentro deste perímetro escorrem em direção do declive, direcionando-se para sua foz no curso d'água principal (Figura 3). Neste estudo, através do software ArcGIS verificou-se que a bacia do Córrego Botafogo possui área de $32,84 \mathrm{~km}^{2}$ e perímetro de $24,34 \mathrm{~km}$ (Tabela 6).

\subsubsection{Densidade de rios, densidade de drenagem, coeficiente de manutenção da bacia}

No cálculo da densidade de rios obtém-se a quantidade de cursos d'água por $\mathrm{km}^{2}$, podendo verificar se a bacia é bem servida de boa rede de canais ou não. Sua importância é fundamental, pois através deste parâmetro ocorre a representatividade do comportamento hidrográfico dentro de seus aspectos fundamentais e a capacidade de gerar novos canais de drenagens. A densidade de rios na bacia do Córrego Botafogo (Figura 3) foi de 0,12 cursos d'água por quilômetro quadrado da bacia (Tabela 6) caracterizando a área como pouco drenada uma vez que, para ser considerada bem drenada, a bacia deve possuir um canal por $\mathrm{km}^{2}$.

A importância da densidade de drenagem está ligada ao estudo de bacias hidrográficas, já que representa uma relação inversa com o comprimento dos rios. Entende-se que à medida que aumenta o valor numérico da densidade há diminuição quase proporcional do tamanho dos componentes fluviais das bacias de drenagem. A densidade de drenagem pode variar de $0,5 \mathrm{~km}\left(\mathrm{~km}^{2}\right)^{-1}$ (bacias mal drenadas devido a elevada permeabilidade ou precipitação escassa) a $3,5 \mathrm{~km}\left(\mathrm{~km}^{2}\right)^{-1}$ (bacias excepcionalmente bem drenadas ocorrendo em áreas com elevada precipitação ou muito impermeáveis). Na bacia do Córrego Botafogo a densidade de drenagem é de 0,58 km de canal por $\mathrm{km}^{2}$ de área (Tabela $6)$.

O coeficiente de manutenção tem o objetivo de fornecer a área mínima necessária para a manutenção de um metro de canal de escoamento e, para a bacia do Córrego Botafogo, o coeficiente correspondeu a 1712,2 m (Tabela 6).

Tabela 6 - Análise Areal da Bacia do Córrego Botafogo

\begin{tabular}{lc}
\hline \multicolumn{1}{c}{ Parâmetros } & Resultados \\
\hline Densidade de rios $\left(\mathrm{km}^{-2}\right)$ & 0,12 \\
\hline Densidade de drenagem $\left(\mathrm{km}^{-1}\right)$ & 0,58 \\
\hline Coeficiente de manutenção $(\mathrm{m})$ & 1712,20 \\
\hline Área $\left(\mathrm{km}^{2}\right)$ & 32,84 \\
\hline Perímetro $(\mathrm{km})$ & 24,34 \\
\hline
\end{tabular}


4.3.3. Relação entre o comprimento do rio principal e a área da bacia

A relação entre a área da bacia $\left(32,84 \mathrm{~km}^{2}\right)$ e o percurso do canal principal $(10,93 \mathrm{~km})$ é de $41,3 \mathrm{~km}$. Verificase na bacia do Córrego Botafogo que, com essa relação, a cada $\mathrm{km}^{2}$ de área da bacia há uma drenagem de $0,33 \mathrm{~km}$.

\subsection{Análise Hipsométrica da Bacia Hidrográfica do Córrego Botafogo}

4.4.1. Amplitude altimétrica, coeficiente de massividade e coeficiente orográfico

Na bacia hidrográfica do Córrego Botafogo o ponto de maior elevação está localizado na cota $890 \mathrm{~m}$, e a cota mínima situa-se na altura da foz do Córrego Botafogo, na cota $692 \mathrm{~m}$ em relação ao nível do mar. A amplitude altimétrica dos rios da bacia encontra-se na Tabela 7. Já conceituados no subitem 3.3. em Metodologia para Estudo Hipsométrico da Bacia, os índices coeficientes de massividade e orográfico facilitam a compreensão das deformidades geomorfológicas da bacia hidrográfica do Córrego Botafogo (Quadro 1,Tabela 7).

Tabela 7 - Análise Hipsométrica da bacia do Córrego Botafogo

\begin{tabular}{|c|c|c|c|c|c|c|}
\hline \multirow{2}{*}{ Curso d'água } & \multicolumn{2}{|c|}{ Altitude (m) } & \multirow{2}{*}{$\begin{array}{c}\text { Amplitude } \\
\text { Altimétrica (m) }\end{array}$} & \multirow{2}{*}{$\begin{array}{l}\text { Altura média } \\
\text { (m) }\end{array}$} & \multicolumn{2}{|c|}{ Coeficientes } \\
\hline & Nascente & Foz & & & Massividade $\left(10^{-5} \mathrm{~m}^{-1}\right)$ & Orográfico \\
\hline Córrego Botafogo & 844 & 701 & 143 & 772,5 & 2,35 & 0,02 \\
\hline Córrego Sumidouro & 818 & 765 & 53 & 791,5 & 2,41 & 0,02 \\
\hline Córrego Areião & 827 & 765 & 62 & 796 & 2,42 & 0,02 \\
\hline Córrego Capim-Puba & 740 & 703 & 37 & 721,5 & 2,2 & 0,02 \\
\hline
\end{tabular}

\subsubsection{Relação de relevo e índice de rugosidade}

O parâmetro hipsométrico Índice de rugosidade (Ir) combina as qualidades de declividade e comprimento das vertentes com a densidade de drenagem, expressando-se como número adimensional. A Tabela 8 mostra os resultados obtidos sobre tal parâmetro na bacia do Córrego Botafogo, bem como a Relação de relevo (Rr) na bacia.

Tabela 8 - Índice de rugosidade e Relação de relevo da bacia do Córrego Botafogo

\begin{tabular}{cccccc}
\hline & $\mathbf{H ~ ( m )}$ & & $\mathbf{D d}\left(\mathbf{k m}^{-\mathbf{1}}\right)$ & $\mathbf{I r}$ & $\operatorname{Rr}\left(\mathbf{m}^{-1}\right)$ \\
\hline $\mathbf{P 1}$ & & $\mathbf{P 2}$ & 0,58 & 0,1 & 0,034 \\
\hline 890 & & 692 & & & \\
\hline
\end{tabular}

\subsubsection{Sumário hidromorfométrico da bacia hidrográfica do Córrego Botafogo}

Na Tabela 9 seguem os resultados obtidos no estudo hidromorfométrico da bacia de estudo. 
Tabela 9 - Sumário das análises hidromorfológicas da bacia do Córrego Botafogo

\begin{tabular}{|c|c|}
\hline Hidromorfologia da bacia hidrográfica do Córrego Botafogo & Valores Obtidos \\
\hline Ordem dos canais na bacia & TABELA 2 \\
\hline Relação bifurcação (média) & 1 \\
\hline Índice de sinuosidade (muito reto) & $14,27 \%$ \\
\hline Relação entre o comprimento médio dos canais de cada ordem & Tabela 3 \\
\hline Comprimento do canal principal & $10,93 \mathrm{~km}$ \\
\hline Equivalente vetorial & $9,37 \mathrm{~km}$ \\
\hline Gradiente do canal principal & $143 \mathrm{~m}$ \\
\hline Área da bacia & $32,84 \mathrm{~km}^{2}$ \\
\hline Perímetro & $24,34 \mathrm{~km}$ \\
\hline Relação entre o comprimento do rio principal e a área da bacia & $0,33 \mathrm{~km}^{-1}$ \\
\hline Densidade de rios & $0,12 \mathrm{~km}^{-2}$ \\
\hline Comprimento total dos canais & $19,18 \mathrm{~km}$ \\
\hline Densidade de drenagem & $0,58 \mathrm{~km}^{-1}$ \\
\hline Coeficiente de manutenção & $1712,20 \mathrm{~m}$ \\
\hline Coeficiente de massividade & $2,35 \cdot 10^{-5} \mathrm{~m}^{-1}$ \\
\hline Coeficiente orográfico & 0,02 \\
\hline
\end{tabular}

\section{Conclusões}

O Córrego Botafogo é o principal corpo hídrico da bacia, possui duas nascentes e extensão de 10,93 km. A bacia do Córrego Botafogo é sub-bacia do Ribeirão Anicuns e se encontra totalmente inserida no perímetro urbano de Goiânia, capital do estado de Goiás, conurbada com o município de Aparecida de Goiânia.

O índice de bifurcação inferior a 2 de bacia hidrográfica confere maior permeabilidade e menor escoamento superficial à respectiva área. No caso da bacia hidrográfica do Córrego Botafogo, no entanto, a área em estudo, encontra-se consideravelmente impermeabilizada vide adensamento urbano que desencadeia alterações na sua dinâmica geomorfológica.

As enchentes no córrego Botafogo têm sido frequentes em decorrência do gradiente altimétrico (143 m) do corpo hídrico que nasce na cota 844 m e deságua na altura de $701 \mathrm{~m}$ em relação ao nível do mar, indicando um relevo com pouco declive que contribui para a rápida concentração das águas de chuva no Córrego Botafogo e nos seus afluentes.

A bacia hidrográfica do Córrego Botafogo é mal drenada $\left(0,58 \mathrm{~km}^{-1}\right)$ sugerindo, portanto, que a ocorrência de alagamentos tem relação com o relevo, uma vez que a amplitude altimétrica da bacia (198 m) facilita o escoamento das águas das chuvas que se concentram na região de mais baixa altitude, que não infiltram, em razão da impermeabilização do solo, desencadeando inundações.

\section{Agradecimentos}

Os autores agradecem à FAPEG (Fundação de Amparo à Pesquisa do Estado de Goiás), à UFG/EECA/PPGEAS (Universidade Federal de Goiás / Escola de Engenharia Civil e Ambiental / Programa de PósGraduação em Engenharia Ambiental e Sanitária) e à CPRM/SGB (Companhia de Pesquisa de Recursos Minerais / 
Serviço Geológico do Brasil - empresa pública de pesquisa do Ministério de Minas e Energia) pelo fomento que viabilizou o desenvolvimento deste trabalho.

\section{Referências}

CARDOSO, M. R. D.; MARCUZZO, F. F. N. Estudo da morfologia areal da bacia do Rio Araguaia utilizando MDE ASTER. Revista Geoaraguaia. 2011, 1(2), 69 a 76. Disponível em: <http://revistas.cua. ufmt.br/geoaraguaia/index.php/geo/article/view/11/11>. Acesso em : 23 Jan. 2017.

CARDOSO, M. R. D.; PINTO FILHO, R. DE F.; ROMERO, V.; MARCUZZO, F. F. N. Detalhamento da Área da Sub-Bacia 63 na Região Hidrográfica do Rio Paraná. In: XL Congresso Brasileiro de Engenharia Agrícola (CONBEA), 40, 2011, Cuiabá. Anais... Jaboticabal: UNESP, 2011. Artigos. CD-ROM. Disponível em: <https://drive.google.com/open?id=0B6T7sNg_aVgObklYOTR1VnlDMWM>. Acesso em: 27 Mar. 2017.

CARDOSO, M. R. D.; PINTO FILHO, R. DE F.; ROMERO, V.; MARCUZZO, F. F. N. DETALHAMENTO areal da sub-bacia 17 na região hidrográfica do rio amazonas. In: XL Congresso Brasileiro de Engenharia Agrícola (CONBEA), 40, 2011, Cuiabá. Anais... Jaboticabal: UNESP, 2011. Artigos. CD ROM. Disponível em: <https://drive.google.com/file/d/0B6T7sNg_aVgOYTFfNFJ6QkdqM1E/view?usp=sharing>. Acesso em: 27 Mar. 2017.

CARDOSO, M. R. D.; PINTO FILHO, R. DE F.; ROMERO, V.; MARCUZZO, F. F. N. Descrição da linearidade da sub-bacia 17 na região hidrográfica do rio amazonas. In: XL Congresso Brasileiro de Engenharia Agrícola (CONBEA), 40, 2011, Cuiabá. Anais... Jaboticabal: UNESP, 2011. Artigos. CD-ROM. Disponível em: <https://drive.google.com/open?id=0B6T7sNg_aVgOM2ctRjNUUWhUZDg>. Acesso em: 27 Mar. 2017.

CASSETI, V. Geomorfologia do município de Goiânia. Boletim Goiano Geografia. 1992, 12(1): 64-85. Disponível em: <http://dx.doi.org/10.5216/bgg.v12i1.4377>. Acesso em: 23 Jan. 2017.

\section{CHRISTOFOLETTI, A. Geomorfologia. 2nd ed. São Paulo, SP: Edgard Blucher, 1980.}

CUNHA, BCC. Impactos sócio-ambientais decorrentes da ocupação da planície de inundação do ribeirão Anicuns: o caso da Vila Roriz. Dissertação. Goiânia: Instituto de Estudos Socioambientais/UFG; 2000. 207 p.

GOIÂNIA. Prefeitura Municipal de Goiânia: Revisão e Detalhamento da Carta de Risco e Planejamento do meio Físico do Município de Goiânia. Goiânia (Goiás): Prefeitura de Goiânia, 2008. 217 p. Disponível em: <http://www.goiania.go.gov.br/download/aprovnet/Carta_Risco/Relatorio_Carta_Risco_IA.pdf>. Acesso em: 27 Mar. 2017.

GOIÁS. SECRETARIA DE INDÚSTRIA E COMÉRCIO. Hidrogeologia do estado de Goiás e Distrito Federal. Goiânia, GO: Superintendência de Geologia e Mineração, 2006. 236 p. Disponível em: <http:// www.sieg.go.gov.br/downloads/Livro_Hidrogeologia.pdf>. Acesso em: 27 Mar. 2017.

GOULARTE, E. R. P. ; MARCUZZO, F. F. N. ; MACEDO, F. C. SRTM 1-arc interpolado e o SRTM 3-arc na delimitação automática da sub-bacia do Alto Meia Ponte em Goiás. In: XIII Simpósio de Recursos Hídricos do Nordeste, 2016, Aracaju. Anais.... Porto Alegre: ABRH, 2016. v. 1. p. 1-10. Disponível em: <http://rigeo.cprm.gov.br/xmlui/handle/doc/17190>. Acesso em: 27 Mar. 2017.

GOUlARTE, E. R. P.; MARCUZZO, F. F. N.; MACEDO, F. C. Estudo Morfométrico da Área de Contribuição da Bacia Hidrográfica a Montante de Goiânia/GO. Revista GeoAraguaia, v. Edição, p. 147162, 2013. Disponível em: <http://revistas.cua.ufmt.br/geoaraguaia/index.php/geo/article/view/52/52>. Acesso em: 27 Mar. 2017. 
HORTON, R. E. Erosinal development of streams their drainage basins: hidrophysical approach to quantitative morphology. Bulletin of the Geological Society of America, Colorado. 1945, (56): 275-370.

IBGE. Estatística Populacional - Censo 2010. 2010. Disponível em <http://www.ibge.gov.br/cidadesat/link. php?uf=to>. Acesso em 29 jan 2017.

MACHADO, G.; SOUZA, J. O. P. Análise morfométrica da bacia hidrográfica do rio Chôco-Ibaiti-PR. In: Anais do X Encontro de Geógrafos da América Latina [Internet], 2005, março, 8366-8382, São Paulo, Brasil. 2005. Disponível em: <http://docplayer.com.br/9309363-Analise-morfometrica-da-bacia-hidrografica-dorio-choco-ibaiti-pr.html>. Acesso em: 27 Mar. 2017.

MACHADO, J. L. F.; MARCUZZO, F. F. N. Aquíferos da Bacia Hidrográfica do Rio Itajaí no Estado de Santa Catarina. In: Anais do 21ํㅗำósio Brasileiro de Recursos Hídricos [Internet], 2015, novembro, 22-27, Distrito Federal, Brasil. 2015. Disponível em: <http://www.evolvedoc.com.br/sbrh/detalhes-217_aquiferosda-bacia-hidrografica-do-rio-itajai-no-estado-de-santa-catarina>. Acesso em: 27 Mar. 2017.

MARCUZZO, F. F. N.; CARDOSO, M. R. D.; PINTO FILHO, R. DE FARIA; ROMERO, V. Caracterização Hidromorfológica da Bacia do Vale do Itajaí. In: XIX Simpósio Brasileiro de Recursos Hídricos, 2011, Maceió. Anais.... Porto Alegre: ABRH, 2011. v. 1. p. 1-20. Disponível em: <http://rigeo.cprm.gov.br/xmlui/ handle/doc/17404>. Acesso em: 27 Mar. 2017.

MARCUZZO, F. F. N.; OLIVEIRA, N. DE L.; CARDOSO, M. R. D.; TSCHIEDEL, A. F. Detalhamento Hidromorfológico da Bacia do Rio Paraíba. In: XI Simpósio de Recursos Hídricos do Nordeste, 2012, João Pessoa. Anais.... Porto Alegre: ABRH, 2012. v. 1. p. 1-20. Disponível em: <http://rigeo.cprm.gov.br/xmlui/ handle/doc/1095>. Acesso em: 27 Mar. 2017.

MARCUZZO, F. F. N.; ROMERO, V.; CARDOSO, M. R. D. Detalhamento Hidromorfológico da Bacia do Rio Mundaú. In: XIX Simpósio Brasileiro de Recursos Hídricos, 2011, Maceió. Anais.... Porto Alegre: ABRH, 2011. v. 1. p. 1-20. Disponível em: <http://rigeo.cprm.gov.br/xmlui/handle/doc/17403>. Acesso em: 27 Mar. 2017.

MARCUZZO, F. F. N.; ROMERO, V.; CARDOSO, M. R. D.. Tendência do número de dias de chuva no estado do Tocantins e a relação dos seus extremos com o Índice Oceânico Niño. Boletim de Geografia. 2014, 32(1):1-16. Disponível em: <http://ojs.uem.br/ojs/index.php/BolGeogr/article/view/18235/pdf_13>. Acesso em: 23 Jan. 2017.

MARCUZZO, F. F. N.; ROMERO, V; CARDOSO, M. R. D.; PINTO FILHO, R. DE FARIA. Detalhamento Hidromorfológico da Bacia do Rio Doce. In: XIX Simpósio Brasileiro de Recursos Hídricos, 2011, Maceió. Anais.... Porto Alegre: ABRH, 2011. v. 1. p. 1-20. Disponível em: <http://rigeo.cprm.gov.br/xmlui/handle/ doc/17402>. Acesso em: 27 Mar. 2017.

MARTINS JÚNIOR, O. P. Uma cidade ecologicamente correta. AB Editora. Goiânia: 1996.

MELATI, M. D.; MARCUZZO, F. F. N. Mapeamento Fisiográfico Básico das sub-bacias Pertencentes à Bacia do Rio Uruguai. In: XXI Simpósio Brasileiro de Recursos Hídricos, 2015, Brasília. Anais.... Porto Alegre: ABRH, 2015. v. 1. p. 1-8. Disponível em: <http://rigeo.cprm.gov.br/xmlui/handle/doc/15053>. Acesso em: 27 Mar. 2017.

PEEL, M. C.; FINLAYSON, B. L.; MCMAHON, T. A. Updated World Map of the Köppen-Geiger Climate Classification. Hydrology and Earth System Science. 2007, 4(2):439-473. Disponível em: <https://hal. archives-ouvertes.fr/hal-00298818/document>. Acesso em: 23 Jan. 2017.

PINTO FILHO, R. DE F.; CARDOSO, M. R. D.; ROMERO, V.; MARCUZZO, F. F. N. Estudo da Linearidade da Sub-Bacia 63 na Região Hidrográfica do Paraná. In: XL Congresso Brasileiro de Engenharia Agrícola (CONBEA), 40, 2011, Cuiabá. Anais... Jaboticabal: UNESP, 2011. Artigos. CD-ROM. Disponível em: $<$ https://drive.google.com/open?id=0B6T7sNg_aVgOcURoeWFlQTR2Q2c>. Acesso em: 27 Mar. 2017. 
PINTO, L. V. A.; BOTELHO, S. A.; DAVIDE, A. C.; FERREIRA, E. Estudo das nascentes da bacia hidrográfica do Ribeirão Santa Cruz, Lavras, MG. Scientia Florestalis. 2004. (65): 197 - 206. Disponível em: <http:// www.ipef.br/publicacoes/scientia/nr65/cap19.pdf >. Acesso em: 27 Mar. 2017.

ROMERO, V. CARRITILHA, C. C.; MARCUZZO, F. F. N.; BARROS, G. R. Correlação da variação da temperatura na parte sul do Oceano Atlântico com a precipitação pluviométrica no estado de Goiás. Ciência e Natura. 2014, 35(2):232-245. Disponível em: <https://periodicos.ufsm.br/cienciaenatura/article/ view/12576>. Acesso em: 27 Mar. 2017.

ROMERO, V.; CARDOSO, M. R. D.; PINTO FILHO, R. DE F.; MARCUZZO, F. F. N. Análise Hipsométrica da Sub-Bacia 63 na Região Hidrográfica do Paraná. In: XL Congresso Brasileiro de Engenharia Agrícola (CONBEA), 40, 2011, Cuiabá. Anais... Jaboticabal: UNESP, 2011. Artigos. CD-ROM. Disponível em: <https://drive.google.com/open?id=0B6T7sNg_aVgOLThoQmhyelNHUOU>. Acesso em: 22 set. 2015.

SANTANA, N. M. P. de.; CASTRO, S. S. de; STONE, L. F.; SILVA, S. C. da. Chuvas, erosividade, erodibilidade, uso do solo e suas relações com focos erosivos lineares na alta bacia do rio Araguaia. Sociedade e Natureza, Uberlândia, 2007;19(2): 103-121. Disponível em: <http://www.seer.ufu.br/index. php/sociedadenatureza/article/view/9272/5707>. Acesso em: 23 Jan. 2017.

SILVA JÚNIOR, J. L. R.; PADILHA, T. F., REZENDE, J. E., RABELO, E. C. A., FERREIRA, A. C. G., RABAHI, M. F. Efeito da sazonalidade climática na ocorrência de sintomas respiratórios em uma cidade de clima tropical. Jornal Brasileiro de Pneumologia. 2011;37(6):759 a 767. Disponível em: <http://www.scielo.br/ scielo.php?script=sci_arttext\&pid=S1806-37132011000600009>. Acesso em: 23 Jan. 2017.

STRAHLER, A. N. Dynamic basis of geomorphology. Bulletin Geological Society America. 1952, 63(9): 923938.

STRAHLER, A. N. Quantitative analysis of watershed geomorphology. Transactions of American Geophysical Union. 1987(38): 913-920.

TSCHIEDEL, A. F.; PICKBRENNER, K.; MARCUZZO, F. F. N. Análise Hidromorfológica da Sub-Bacia 87. In: XI Simpósio de Recursos Hídricos do Nordeste, 2012, João Pessoa. Anais...: ABRH, 2012. v. 1. p. 1-20. Disponível em: <http://rigeo.cprm.gov.br/xmlui/handle/doc/17426>. Acesso em: 27 Mar. 2017.

TUCCI, C. E. M.; HESPANHOL, I.; CORDEIRO NETTO, O. M. Cenários da gestão da água no Brasil: uma contribuição para a visão mundial da água. Revista Brasileira de Recursos Hídricos. 2000;5( 3): 31-43. Disponível em: <http://rhama.com.br/blog/wp-content/uploads/2017/01/cenarios-da-gestao-da-agua-nobrasil-1.pdf>. Acesso em: 23 Jan. 2017.

WHITE, P.; RUBLE, C. L.; LANE, M. E. The effect of changes in land use on nitrate concentration in water supply wells in southern Chester County, Pennsylvania. Environmental Monitoring and Assessment. 2013, 185(1):643-651. Disponível em: <https://link.springer.com/article/10.1007/s10661-012-2581-5>. Acesso em: 27 Mar. 2017.

ZOBY, J. L.; BERTOLO, R. A.; FERNANDES, A. J.; HIRATA, R. Hidrogeología del Brasil: una breve crónica de las potencialidades, problemática y perspectivas. Boletín Geológico y Minero. 2006, 217(1), 25-36. Disponível em: <http://aguas.igme.es/Boletin/2006/117_1_2006/Art.2.PDF>. Acesso em: 23 Jan. 2017. 